\title{
Evaluation of `Levels of Tax Understanding and Compliance in Batang Regency, Central Java, Indonesia
}

\author{
Dian Anggraeni ${ }^{1, *}$ Ika Pratiwi ${ }^{2}$ Tineke Erfina $^{3}$
}

\author{
${ }^{1,2}{ }^{3}$ Diponegoro University, Indonesia \\ *Corresponding author.Email: diananggraenii@lecturer.undip.ac.id
}

\begin{abstract}
This study focuses on understanding, knowledge, and compliance using the dimensions of tax implementation and reporting for individual taxpayers. This study used data from respondents of tax officers of Pratama Batang Tax Office, taxpayers in Batang Regency, and secondary data from documents related to tax understanding and compliance in 2020-2021. This study used data obtained by various data collection techniques, namely literature study, documentation, observation, and in-depth interviews. The research period began on April 1, 2021 and ended on October 31, 2021. Data testing was carried out after all data had been collected by validity and reliability tests before being analyzed. The validity test is done by triangulation and member checking. The study results show that (1) understanding of the importance of taxes in Batang Regency is good and increases every year with a percentage of around $90 \%$ as evidenced by increased registration and reporting. Tax understanding for taxpayers in Batang Regency is provided through education carried out by the counseling section of KPP Pratama Batang in various ways, both offline and online. (2) Tax knowledge in Batang Regency is sufficient because people understand the meaning of taxes, the importance of taxes, and tax benefits. (3) Tax compliance of taxpayers in Batang Regency based on regulation is good. Various efforts have been made and all sections synergize to improve tax compliance in Batang Regency.
\end{abstract}

Keywords: Tax Understanding, Tax Knowledge, Tax Compliance, Tax General Provisions and Procedures.

\section{INTRODUCTION}

The development of convenience in paying and reporting taxes from year to year is increasingly being improved to make it easier for taxpayers to carry out their tax obligations. This development should be accompanied by an excellent level of tax awareness and understanding of the tax subject concerned so that both of them synergize with each other to increase state revenue. The importance of understanding taxes is also one factor that encourages people to be more aware and willing to pay taxes.

One of the problems that tax officers pay attention to is tax compliance behavior due to tax evasion and tax avoidance that affect tax collection, which is supposed to be used for economic and community prosperity purposes in a country [2]. In addition to understanding taxes, tax compliance is also an important factor in this regard. After the community understands what taxes are, it is expected to pay taxes. Tax understanding and tax compliance will synergize in making people aware of the importance of paying taxes.

Bornman and Ramutumbu's study on the conceptual framework of tax knowledge found three elements of tax knowledge, namely taxes in general, tax procedures and laws, and tax knowledge [3]. Tax knowledge, in general, relates to the need to have tax awareness, while knowledge of tax procedures refers to understanding tax compliance procedures and the need to understand tax regulations and laws.

Some reviews by McKerchar, Kornhauser, Kirchler, Pickhardt and Printz, and Hofmann et al. found factors that influence tax compliance, namely personal factors and social norms, tax knowledge, perceptions of justice, taxpayer demographics, and taxpayer attitudes and motivation to play a role in tax compliance [4] [5] [6] [7] [8]. Based on several 
reviews from the above researchers, tax knowledge is one-factor affecting tax compliance. It indicates that the two synergize and have a positive relationship. Taxpayer motivation and attitude is also supporting factor that influences tax compliance.

The tax compliance rate in Batang Regency in 2017 reached $70 \%$. Furthermore, the tax revenue received by Batang Regency in the first half of 2018 reached $44.32 \%$ of the target, with a growth rate of 26.58\%. Tax achievement was obtained from 22 sectors: agriculture, mining, and processing industry. KPP Pratama Batang positioned itself as the only one of the seventeen tax offices in Central Java whose tax revenues exceeded the target in the first half of 2018 [9]. Batang Regency can be one of the districts with a good level of tax compliance. Tax compliance synergizes with tax understanding. If the people of Batang Regency comply with taxes, it is also hoped that the community will have good knowledge and understanding of taxes. This study intended to evaluate the actual understanding of taxes in Batang Regency.

Knowledge and understanding of taxes in Batang Regency should be good, considering that tax compliance is already good. This study also intended to examine tax compliance in Batang Regency, considering that its achievement has met the target. This study aimed to describe the level of tax understanding, knowledge and evaluate tax compliance in Batang Regency in 2020.

\section{LITERATURE REVIEW}

A tax according to Law Number 16 of 2009 on Tax General Provisions and Procedures Article 1 Paragraph 1 is a mandatory contribution owed by an individual or entity to the state based on the law with no direct compensation and is used for state development as much as needed for the prosperity of the people [15]. According to Mardiasmo, there are two tax functions: the budget and the regulating functions [10]. Taxes have an essential function for the state which will benefit the community. There are several obstacles related to tax collection as stated by Mardiasmo, namely passive resistance from people who are reluctant to pay taxes and active resistance from taxpayers' actions to avoid taxes such as tax avoidance and tax evasion [10].

A critical theory that explains taxes is the theory of stewardship. This theory can be applied to the accounting research of public sector organizations such as government and non-profit organizations
[11]. Since the beginning, the development of accounting public sector organizations has been prepared to meet the information needs for the relationship between stewards and principals. According to organizational goals, stewards and principals agree to use a trust contract and act together. Thus, the appropriate model, in this case, is stewardship theory. Concerning this, society acts as the principal who entrusts their trust to the government as the stewards. Stewardship theory in this study was used to explain the existence of KPP Pratama as an institution that is trusted to act in the public interest by carrying out its duties and functions appropriately, being responsible for the financial funds entrusted to it, to maximize economic goals, public services, and community welfare.

A study that is quite relevant to the current study being carried out is Bornman and Ramutumbu's study that examined the conceptual framework of tax knowledge [3]. The purpose of the study was to develop a conceptual framework of tax knowledge to analyze and discuss tax knowledge as a factor influencing tax compliance. The study revealed three elements of tax knowledge, namely tax in general, tax procedures and laws, and tax knowledge.

\section{METHODOLOGY}

The researchers designed the study as a case study with a qualitative approach. This approach allows researchers to examine a person's experience in detail using a series of specific research methods, such as in-depth interviews, observation, focus group discussions (FGD), content analysis, visual methods, and biographies [12]. The researchers obtained primary data through direct and in-depth interviews with relevant parties. The parties concerned consisted of three tax officers/employees at the counseling section of KPP Pratama Batang and the community as taxpayers in Batang Regency. Secondary data was obtained by the researchers from KPP Pratama Batang in the form of data on tax understanding and compliance in Batang Regency in 2020-2021 sourced from educational activities, socialization, related documents, and so on which were used as supporting documents in this study. The data used in this study were obtained through various data collection techniques, namely literature study, documentation, observation, and in-depth interviews.

Data analysis carried out for the level of tax understanding used several questions related to taxes in general and tax procedures, while for tax 
compliance using several relevant tax regulations. The regulations used for tax understanding and compliance source from Law Number 16 of 2009 on Tax General Provisions and Procedures. The data analysis technique used in this study was based on Miles et al. [1]: data reduction, data presentation, and conclusion formulation related to tax understanding, knowledge, and compliance using the indicators in Law Number 16 of 2009. The validity test utilized triangulation and member checking techniques. Researchers carried out data testing after all data was collected and before analysis was carried out. The validity test was done by triangulation and member checking as in [13]. The reliability test in this qualitative study was carried out by ensuring whether the transcripts were correct and clear in the research process. Researchers coded the data accurately, reliably, and correctly [14]. Researchers reduced reliability problems by using recording devices with the help of an assistant when conducting interviews.

\section{RESULTS AND DISCUSSION}

\subsection{Tax Understanding in Batang Regency}

Tax understanding becomes a very important thing because it can increase awareness and tax compliance for taxpayers. The Indonesian government regulates taxes into general provisions and tax procedures with the enactment of Law Number 16 of 2009. The tax general provisions and procedures are included in the formal law that makes material law real.

\subsubsection{Tax Understanding Based on Law Number 16 of 2009}

KPP Pratama Batang is the only tax office located in Batang Regency, Central Java, Indonesia. As a tax organization, KPP is obliged and responsible for properly realizing and supervising the selfassessment taxation system implementation. Through the extension section, KPP Pratama Batang is also tasked with providing socialization, education, and counseling related to taxes to taxpayers in Batang Regency. Tax understanding in Batang Regency can be seen from the following indicators.

1. Understanding the functions, benefits, and importance of taxes by taxpayers based on Chapter I Article 1 and Article 2 of Law Number 16 of 2009 in Batang Regency is good, as seen from the increasing number of new taxpayer registrations and based on field observations. According to the self-assessment system, most taxpayers understand the functions and benefits of taxes with a percentage of around $80 \%$, which can be seen from voluntary tax payments. The counseling section provides education on the importance of taxes when registering for a tax ID number (NPWP) or socialization. There is also a tax education program named Tax Go To School (TGTS) so that the younger generation is tax literate from an early age.

2. Taxpayer awareness in Batang Regency in obtaining NPWP and reporting business to be confirmed as Taxable Entrepreneurs (PKP) based on Law Number 16 on 2009 Chapter II Article 2 Paragraph 1 and Paragraph 2 is considered good because it increases every year as seen from the registered data. Taxpayers now need NPWP to fulfill requirements for work registration, paying by credit, and so on. Before applying to be confirmed as a PKP, a taxpayer will consult regarding the benefits, functions, and obligations of PKP.

3. The technical understanding of SPT filling by taxpayers in Batang Regency according to Law Number 16 of 2009 Chapter II Article 3 Paragraph 1 is sufficient because it is rare to find incorrect SPT as SPT reporting can be accepted only if the fields are formally correct and complete, meaning that they formally understand.

4. KPP Pratama Batang carries out service improvement in this technological era according to Law Number 16 of 2009 Chapter II Article 6 Paragraph 2 by following technological developments. Therefore, services are now mostly done online.

5. Efforts to educate and encourage taxpayers in Batang to report taxes as carried out by KPP Pratama Batang according to Law Number 16 of 2009 Chapter III Article 17C Paragraph 5 is considered good because it has been various ways following job desks of each section in the KPP.

6. The understanding of taxpayers in Batang Regency regarding the procedure for applying for installments or delays in payment according to Law Number 16 of 2009 Chapter IV Article 22 Paragraph 2 is sufficient. Taxpayers in Batang Regency sufficiently understand the process and when they want to apply for installments, they will usually consult first. 
7. Understanding related to counseling and guidance for filing objections by KPP Pratama Batang to taxpayers in Batang Regency according to Law Number 16 of 2009 Chapter V Article 25 Paragraph 1 is sufficient because taxpayers pretty much understand the procedure. Counseling has been carried out by consultation through the helpdesk.

8. The understanding of bookkeeping and recording carried out by KPP Pratama Batang to taxpayers in Batang Regency according to Law Number 16 of 2009 Chapter IV Article 28 Paragraph 9 is sufficient because they have been educated during the socialization of SPT reporting. Taxpayer recordings in Batang Regency is insufficient, except for those with a turnover approaching 1Billion, which is considered sufficient, while bookkeeping is good because they usually hire a third person, namely tax consultants.

9. The professionalism of KPP Pratama Batang employees to comply with Law Number 16 of 2009 Chapter VII Article 36A Paragraph 1 is good because they have guidelines. The guidelines follow the civil apparatus regulations, Directorate General of Taxes (DGT) strategic plans, and the Ministry of Finance's values regarding professionalism.

\subsubsection{Conclusion Tax Understanding in Batang Regency}

Based on regulations, KPP Pratama Batang provides a good tax understanding to taxpayers in Batang Regency. Tax socialization to make taxpayers in Batang understand taxes is carried out in various ways, both offline and online, following the times and adjusting to the conditions of the Covid-19 pandemic to make it safer and more comfortable. Education is carried out by the counseling section of KPP Pratama Batang. The understanding of the importance of taxes by taxpayers increases yearly with a percentage of about $90 \%$, as evidenced by increased registration and reporting. However, tax awareness needs to be increased, especially materially.

According to the stewardship theory, the existence of KPP Pratama Batang as an institution is trusted by the public or taxpayers to act in the public interest by carrying out their duties and functions related to taxes appropriately in order to realize a self-assessment system. KPP Pratama Batang is expected to continue to provide education and socialization of tax understanding more diversely and routinely to taxpayers in Batang Regency so that taxpayer awareness, especially material awareness, can be increased.

\subsection{Tax Knowledge in Batang Regency}

Tax knowledge is no less important than tax understanding and tax compliance. The results of observations and interviews conducted by the researchers with 10 people in Batang Regency indicate that people understand taxes, the importance of taxes for Batang Regency and Indonesia, and the benefits they gain by paying taxes. The public already has basic knowledge regarding the definition and benefits of taxes. Meanwhile, another interesting thing is that the public does not understand many things related to taxes, for example, the procedure for filling out the SPT appropriately and correctly. Most of the people interviewed by the researchers still have difficulty and depend on officers or relatives when filling out tax returns.

\subsection{Tax Compliance in Batang Regency}

The tax revenue of KPP Pratama Batang in 2020 reached $98.29 \%$ with a realization of Rp686,254,283,307.00 of the specified target of Rp698,195,183. The tax compliance rate in Batang Regency in 2017 reached $70 \%$. In this case, it is hoped that tax compliance will also increase. A good taxpayer will, of course, adhere and is obedient to taxes. Tax compliance in this study was seen using Law Number 16 of 2009.

\subsubsection{Tax Compliance Based on Law Number 16 of 2009}

As a tax organization, KPP is obliged and responsible for properly realizing and supervising the self-assessment taxation system implementation. Tax compliance in Batang Regency can be seen from various indicators as follows.

1. Efforts to deliver the deadline for submitting SPT as carried out by KPP Pratama Batang to taxpayers in Batang Regency have been good through various efforts according to Law Number 16 of 2009 Chapter II Article 3 Paragraph 5. Efforts are made by contacting taxpayers and employers as well as holding open houses at KPP in MarchApril. Deliverance of the deadline is also made through KPP's social media accounts and banner advertisements installed in strategic places. 
2. Compliance with timely reporting of SPT by taxpayers in Batang Regency according to Law Number 16 of 2009 Chapter II Article 3 Paragraph 5 is considered sufficient because most of them are on time. As seen from the taxpayer SPT data one by one, some taxpayers are on time and others are not on time. The percentage of taxpayers who were on time in 2020 is in the range of $65-75 \%$. Now, entering the transition period from 3rd quarter to 4th quarter, it is still $95 \%$, only $5 \%$ to achieve the target.

3. Tax compliance concerning tax payments without relying on tax assessment letters by taxpayers in Batang Regency according to Law Number 16 of 2009 Chapter III Article 12 Paragraph 1 is considered good. Tax payments are made before, without, and do not depend on tax assessment letters (SKP). Taxpayers in Batang Regency are aware of paying taxes voluntarily without relying on tax assessment letters.

4. Tax compliance related to tax audits in Batang Regency carried out by KPP Pratama Batang according to Law Number 16 of 2009 Chapter III Article 13 Paragraph 1 is considered good because a separate special section handles it and there is a target for audits carried out. KPP Pratama Batang has carried out inspections because there are targets and realization of the number of inspections. The counseling section conducts an examination when a taxpayer applies to the abolition of NPWP and an explanation of the sanctions. The tax audit will be handled by a special section at the KPP Pratama Batang, namely the audit section.

5. KPP Pratama Batang's efforts to improve tax compliance in Batang Regency according to Law Number 16 Year 2009 Article 13A are carried out in various ways both offline and online and are considered good because all parts work together to improve compliance. Efforts are made with socialization, education, direct visits to taxpayers, tax corners, and online through Zoom meetings due to the Covid-19 pandemic situation. All sections/fields of KPP Pratama Batang have their respective job desks to increase tax compliance actively.

6. The action of KPP Pratama Batang in reducing the misuse of the preliminary refund of tax payments according to Law Number 16 of 2009 Chapter III Article 17D Paragraph 4 has been carried out well since the beginning of the application. Efforts are made at KPP Pratama Batang in the counseling section by checking the data reported in the SPT whether they are correct or not. If a preliminary refund application does not meet the requirements, it will not be processed and formal abuse is stopped with the applicable provisions.

7. Immediate and total tax collection made by KPP Pratama Batang according to Chapter IV Article 20 Paragraph 2 has been carried out in line with applicable regulations. Immediate and total tax collection is rare because it only applies to special cases. The tax collection section of KPP Pratama Batang handles explicitly this matter.

8. Tax audits for corporate taxpayers in Batang Regency who are listed on the stock exchange according to Law Number 16 of 2009 Chapter VI Article 29A will be granted by KPP Pratama Batang if they comply with the provisions.

9. The actions of KPP Pratama Batang in providing a balance of rights and obligations of taxpayers in Batang Regency when responding to audit findings according to Law Number 16 of 2009 Chapter VI Article 31 Paragraph 2 have been carried out correctly and in balance according to the provisions. The examiner party will convey the rights and obligations of an inspection.

10. The form of supervision of compliance with the implementation of tax obligations by KPP Pratama Batang according to Law Number 16 of 2009 Chapter VII Article 35A Paragraph 1 is carried out properly because supervision is a consequence of implementing the selfassessment system. Supervision is carried out and then the relevant department will make a report.

11. The actions of KPP Pratama Batang in dealing with violations of tax administration by taxpayers in Batang Regency have been good because they have gone through various steps taken by the provisions of Law Number 16 of 2009 Chapter VIII Article 38. Steps taken are through appeals, imposition of sanctions, inspections, and tax collection.

\subsubsection{Conclusion Tax Compliance in Batang}

\section{Regency}

Based on regulations, KPP Pratama Batang pays attention to the level of tax compliance in Batang Regency. Taxpayers in Batang Regency are 
responsive and when they do not understand, they will consult and fulfill their tax obligations. Reception and reporting compliance are good, proven by a score of around 7-8 in a 1-10 scale and a percentage of around $90 \%$. Improvement is done by massive socialization. Things that need to be improved for taxpayers in Batang Regency are related to timely reporting and material payments. KPP Pratama Batang hopes that taxpayers always respond to warning letters, so that it can be evaluated every month. If necessary, socialization and tax classes will be carried out in this case. Socialization is held more regularly with scheduled tax classes and Instagram Live every week.

According to the stewardship theory, the existence of KPP Pratama Batang as an institution is trusted by the public or taxpayers to act in the public interest by carrying out their duties and functions related to taxes appropriately in order to realize a self-assessment system. Taxpayers as the principals entrust the mandate and the government, in this case the DGT, represented by KPP as stewards, work together or synergize related to taxes for the state development as much as possible for the prosperity of the state the people.

\section{CONCLUSIONS}

The understanding of the importance of taxes in Batang Regency is good and increases every year with a percentage of around $90 \%$ as evidenced by increased registration and reporting. Tax understanding for taxpayers in Batang Regency is provided through education carried out by the counseling section of KPP Pratama Batang in various ways. However, tax awareness may need to be improved.

Tax knowledge in Batang Regency is sufficient because people understand the meaning of taxes, the importance of taxes, and tax benefits. Tax knowledge related to the technicalities of filling out tax returns (SPT) need to be improved through education and socialization because some people still do not understand.

Tax compliance in Batang Regency based on Law Number 16 of 2009 is sufficient. Various efforts have been made and all sections synergize to improve tax compliance in Batang Regency. Reception and reporting compliance are good, proven by a score of around 7-8 in a 1-10 scale and a percentage of around $90 \%$. Improvement is done by massive socialization. Things that need to be improved for taxpayers in
Batang Regency are related to timely reporting and material payments.

\section{AUTHORS CONTRIBUTIONS}

This study shows tax understanding; tax knowledge is important to improve tax compliance. Based on the study results, it shows that the Covid-19 pandemic conditions in 2020 did not prevent the people of Batang Regency from being tax compliant and paying taxes even though they were in difficult conditions because they realized that taxes were important for a country. Tax revenue during the Covid-19 pandemic can be used to buy medical equipment, vaccines and so on to overcome this situation. In addition, tax understanding and tax compliance of family firms are also important to increase a country's income because when they understand their expectations, they will comply with taxes. The author also hopes that through this research, the public, both individual taxpayers, PKP, corporate taxpayers, and family firms, are always aware of taxes, improve tax understanding, tax knowledge, and tax compliant.

\section{REFERENCES}

[1] Matthew B. Miles, A. Michael Huberman, Johny Saldana, Qualitative Data Analysis $3^{\text {rd }}$ edition, USA, SAGE Publications, 2014.

[2] N. Sharoja Sapiei, J. Kasipillai, U. Cyril Eze, Determinants of Tax Compliance Behaviour of Corporate Taxpayers in Malaysia, eJournal Tax Research, ProQuest, vol. 12, no. 2, pp. 383-409, 2014. https://www.proquest.com/scholarlyjournals/determinants-tax-compliancebehaviour-corporate/docview/1674651800/se-2

[3] Marina Bornman, Pusheletso Ramutumbu, A Conceptual Framework of Tax Knowledge, Meditari Accountancy Research, vol. 27 no. 6, Emerald, pp. 823-839, 2019. DOI: https://doi.org/10.1108/MEDAR-09-2018-0379

[4] M. McKerchar, Design and Conduct of Research in Tax, Law, and Accounting, Sydney, Thomson Reuters, 2010.

[5] Marjorie E. Kornhauser, Normative and Cognitive Aspects of Tax Compliance: Literature Review and Recommendations for the IRS Regarding Individual Taxpayers, Taxpayer Advocate Service, Annual Report to Congress Volume Two, 2007. 
[6] E. Kirchler, The Economic Psychology of Tax Behavior, Cambridge, Cambridge University Press, 2007.

[7] M. Pickhardt, A. Prinz, Behavioral Dynamics of Tax Evasion-a Survey, Journal of Economic Psychology, vol. 40, Elsevier, pp. 1-19, 2014. DOI: https://doi.org/10.1016/j.joep.2013.08.006

[8] E. Hofmann, M. Voracek, Christine Bock, E. Kirchler, Tax Compliance Across Sociodemographic Categories: Meta-Analyses of Survey Studies in 111 Countries, Journal of Economic Psychology, Elsevier, vol. 62, pp. 6371 , 2017.

DOI:

https://doi.org/10.1016/j.joep.2017.06.005

[9] Dina Indriani, Semester Pertama, Pendapatan Pajak Kabupaten Batang Capai 44,32\%, Accessed 1 February 2021, 2018. [Online]. Available:https://jateng.tribunnews.com/2018/07 /10/semester-pertama-pendapatan-pajakkabupaten-batang-capai-4432-persen.

[10] Mardiasmo, Perpajakan, Yogyakarta, ANDI, 2018.
[11] Haliah, Kualitas Informasi Laporan Keuangan Pemerintah Daerah dan Faktor Yang Mempengaruhinya, Disertasi, Universitas Hasanuddin Makassar, 2013. DOI: http://dx.doi.org/10.13140/RG.2.2.19772.95367

[12] M. Hennink, I. Hutter, A. Bailey, Qualitative Research Methods, United Kingdom, SAGE Publications, 2011.

[13] R.K. Yin, Case Study Research Design and Methods 5th ed, California, SAGE Publications, 2014.

[14] J.W. Cresswell, Penelitian Kualitatif \& Desain Riset, Yogyakarta, Pustaka Pelajar, 2015.

[15] Republik Indonesia, Undang-Undang Nomor 16 Tahun 2009 tentang Perubahan Keempat atas Undang-Undang Nomor 6 Tahun 1983 tentang Ketentuan Umum dan Tata Cara Perpajakan, 2009. 